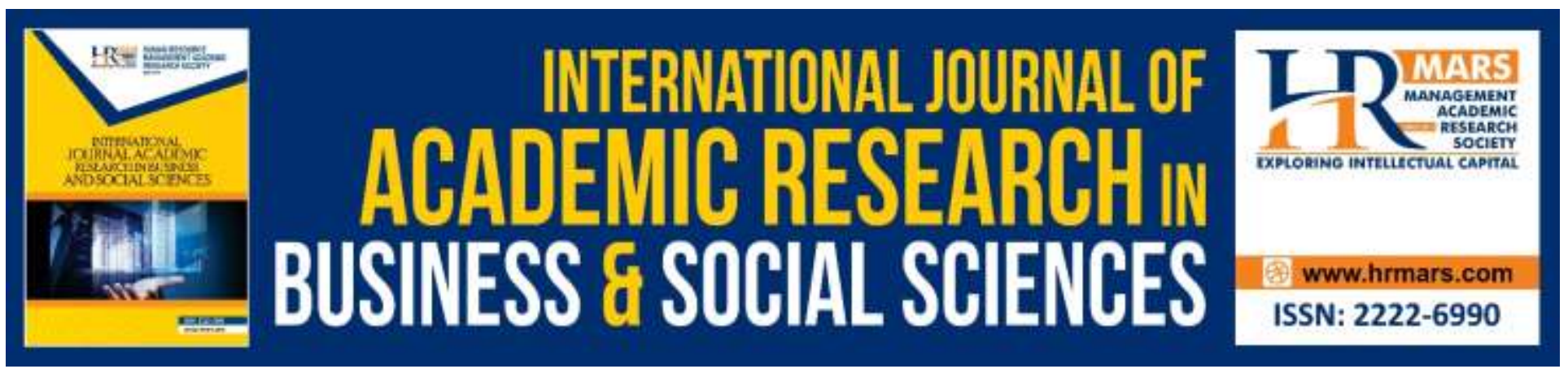

\title{
Influence of Procurement Process on the Performance of Public Entities (A Case Study of Nairobi County Government)
}

Francis Hasborn Gatobu

To Link this Article: http://dx.doi.org/10.6007/IJARBSS/v10-i4/7106

DOI:10.6007/IJARBSS/v10-i4/7106

Received: 19 February 2020, Revised: 02 March 2020, Accepted: 19 March 2020

Published Online: 10 April 2020

In-Text Citation: (Gatobu, 2020)

To Cite this Article: Gatobu, F. H. (2020). Influence of Procurement Process on the Performance of Public Entities

(A Case Study of Nairobi County Government). International Journal of Academic Research in Business and Social Sciences, 10(4), 40-61.

\section{Copyright: (C) 2020 The Author(s)}

Published by Human Resource Management Academic Research Society (www.hrmars.com)

This article is published under the Creative Commons Attribution (CC BY 4.0) license. Anyone may reproduce, distribute, translate and create derivative works of this article (for both commercial and non-commercial purposes), subject to full attribution to the original publication and authors. The full terms of this license may be seen

at: http://creativecommons.org/licences/by/4.0/legalcode

Vol. 10, No. 4, 2020, Pg. $40-61$

http://hrmars.com/index.php/pages/detail/IJARBSS

JOURNAL HOMEPAGE

Full Terms \& Conditions of access and use can be found at http://hrmars.com/index.php/pages/detail/publication-ethics 


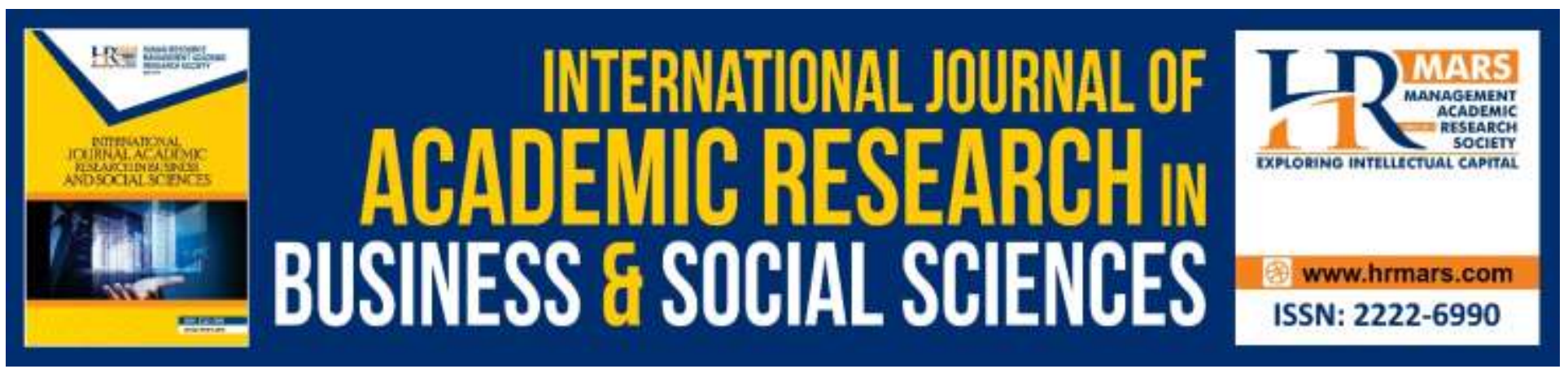

\title{
Influence of Procurement Process on the Performance of Public Entities (A Case Study of Nairobi County Government)
}

\author{
Francis Hasborn Gatobu \\ Meru University of Science and Technology
}

\begin{abstract}
Globally public procurement plays a pivotal role in the provision of goods, works and services in every economy. Enhancement in the performance of the public procurement system is key ingredient for ensuring value for money is achieved in order to safeguard public funds particularly in the implementation of economic pillars such as the "Big Four Agenda" and Vision 2030. This is the case because $60 \%$ of Kenyan budget is spent through procurement contracts. This study sought to investigate the influence of user departments on the performance of procurement process in Kenya. Specific objectives of the study included: To examine the role of specification writing on the performance of public entities in Kenya, To investigate the influence of procurement plan on the performance of public entities in Kenya, To assess the effect of tender evaluation on the performance of public entities in Kenya and To determine the influence of receiving procedure on the performance the public entities in Kenya. The study will be guided by the following theories: resource based theory, systems theory, Expectancy theory and institutional Theory.

Descriptive research design as well as quantitative research design were adopted using both qualitative and quantitative approaches. The target population was 1000 employees of Nairobi County government. The study adopted stratified random sampling to select the sample size of 100 respondents. Data was collected using questionnaires and oral interview. Descriptive statistics was employed aided by statistical package for social sciences version 21 to compute the percentages. Inferential statistics using regression and correlation analysis was applied to assist in examining the relationship between variables.
\end{abstract}

\section{Introduction}

Procurement process begins when the user department identifies the need and forwards a purchase requisition to procurement department for items to be purchased. However, there must be a procurement plan in place to provide procedural guidelines and ensure strict adherence to the procurement budget. The user plays a key role in the procurement process starting from initiation of the need to purchase, preparation of specifications, involvement in opening of quotations, evaluation 
of bids, inspection and acceptance of the goods, works or services (PPDA, 2015). The effectiveness of the procurement process heavily depends on active participation and coordination between the user and procurement department (Arjan \& Van, 2010).

The public procurement process may be viewed as proceeding through various stages of progression. It has been argued (Walker, 2013) that public procurement reform is most likely to succeed when it proceeds through a competitive procurement process. There has to be support from top management as well as the user departments for the whole process to be successful. This is seen as necessary to enable establishment of a robust link in the process by ensuring critical elements which include: procurement plan, preparation of specifications, evaluation and receiving of supplies are accomplished in a timely and responsive manner.

In the global frontier, procurement is governed by the international procurement law as provided by the Rome convention of 2015. The model Law on International public procurement contains procedures and principles aimed at achieving value for money and avoiding abuses in the procurement process. The process is aimed at promoting objectivity, fairness, public participation, competition, transparency and integrity (UNCITRAL, 2011).

In Africa, the African Development Bank standard forms are used for goods sponsored by the Bank. In Rwanda the public procurement process is managed on real-time basis by Rwanda Public Procurement Authority (RPPA) which operates under the Ministry of Finance and Economic Planning. Rwanda has a decentralized public procurement system where by procuring entities have the power to conduct directly their public procurement process. The Public procurement system in Rwanda is governed by six fundamental principles namely: Transparency, Competition, Economy, Efficiency, Fairness and Accountability (RPPA, 2012).

In Kenya, all the standard forms are used depending on the sponsor of the project, with the Public Procurement Oversight Authority (PPOA) standards being used mainly for public goods funded by the Kenya Government (PPOA, 2009). In Kenya, the public procurement is governed by the Public Procurement and Asset Disposal Act of 2015. The PPADA, 2015 abolished the tender committee and the procurement committee and gave power to the Accounting officers to award tenders on recommendation by the Head of Procurement Unit. The Act also among other issues introduced new procurement methods which were not envisaged in the previous Act of, 2005 and the regulations, 2006.

\section{Statement of the Problem}

Public entities are grappling with reduced funding from exchequer, escalating cost of operations and rampant loss of funds through procurement of goods and services (Juma,2018).Enhanced team work among functional departments in an organization can facilitate information sharing which is a critical tool for effective and efficient management of procurement process (Alex, 2011). This will ensure the procuring entity gets value for money and enhance competitive buying which is anchored on the PPADA (2015).

According to Farringtong (2015), Synergy between Procurement and user department plays a critical role in enabling an organization to achieve value for money in the acquisition of goods, works and services. Failure by the procurement department to play their role as outlined by the procurement 
law can result in delays in the delivery of services or loss of public funds. This will result to end user dissatisfaction which may bring about persistent complaints from other stakeholders.

According to Jorge (2015), the most common causes of inefficiency in public procurement process are: delays in preparation of technical specification, failure to start procurement process on time, delay in opening bids, delay in evaluation of bids and failure to award tenders on time.

A number of interventions have been undertaken to address the inefficiencies in the procurement process, they include: capacity building of stakeholders, improved public-private partnerships, development of procurement policies, increased, transparency, accountability and fairness in the procurement process (Nyambariga, 2016). However, these interventions have not been able to address the problem of the lack of coordination between the user and procurement department on the enhancement of the procurement process among the public entities. Therefore, this study seeks to address the need with the view of ensuring the departments work in harmony in order to achieve the overall goals of public sector organizations.

In many instances users prepare and submit inaccurate specifications to procurement department which are returned back to user for review thus causing delays in the process. In view of the above, the two departments must work in harmony in order to achieve the overall goals of the organization (Shirima, 2010).

The main problems facing many public procuring entities is the lack of proper co-ordination between procurement and other functional departments, leading to delays, quality discrepancies, stock outs, high cost in the procurement of goods and this consequently affects the smooth running of an organization and loss of tax payers money. The functional departments departments often fail to share information affecting the procurement process leading to delays in decision making. This further erodes the efforts that are geared towards achieving value for money in the public procurement. Every purchasing function must satisfy the five fundamental rights of procurement which include: right quality, right quantity, right price, right place and right time. This can be achieve when there is adherence to specification from the user department.

The main challenge facing public procuring entities in Kenya today is how to synchronize the objectives of procurement department with the corporate mission of public entities in order to fast track the whole process right from need identification, evaluation of bids, selection of suppliers, award of tenders, contract management/expediting, inspection, receiving and payment of suppliers (Schapper et al, 2012).

In the light of the above, this study seeks to address the knowledge gap by investigating the influence of procurement process on the performance of public entities.

\section{General Objective}

The general objective of the study was to determine the influence of procurement process on the performance of public procuring entities in Kenya

\section{Specific Objectives}

The study was guided by the following specific objectives:

To investigate the influence of procurement plan on the performance of public entities in Kenya

To examine the role of specification writing on the performance of public entities in Kenya.

To assess the effect of tendering process on the performance of public entities in Kenya. 
INTERNATIONAL JOURNAL OF ACADEMIC RESEARCH IN BUSINESS AND SOCIAL SCIENCES Vol. 10, No. 4, April, 2020, E-ISSN: 2222-6990 @ 2020 HRMARS

To determine the influence of Inspection and receiving procedure on the performance the public entities in Kenya.

\section{Research Questions}

The study was guided by the following questions:

What role does procurement plan play on the performance of public entities in Kenya?

What is the role of specification writing on the performance of public entities in

What is the influence of tendering process on the performance of public entities in Kenya?

Is there a relationship between receiving procedure and performance of public entities in Kenya?

\section{Justification of the Study}

This study provided the key highlights of consideration by the policy makers in streamlining public procurement practices in Kenya and beyond. It further provided a solid platform for enabling the government achieve the Big Four Agenda through prudent use of public funds through procurement process. This will further play a complimentary role in attainment of millennium development goals. Public procuring entities are often prone to delays in procurement of goods, works and services resulting from bureaucratic procedures and communication breakdown among functional departments (Baily, 2009).

The findings of this study will be of great importance to procurement professionals since it will inform the key areas of procurement process that requires joint problem solving and decision making mechanisms with user departments. The findings will also be useful to academicians who may conduct further research on the same area in a different set up. The findings will further guide the policy makers in identifying the key areas of procurement process that should be aligned with the changes in the operating environment to make public procurement more responsive.

Nairobi county was selected as a case study due to the volume of procurements undertaken within this county and also owing to the fact that Nairobi county contributes $60 \%$ of our GDP ( KNBS, 2017).

\section{Literature Review}

Introduction

This chapter discussed the literature review of the study. The main reason for literature review was to explore the available and existing information which has been availed by previous researchers in the same area of research. The literature review covered theoretical studies, empirical studies related to the area of study, critique on the existing literature and conceptual framework. The literature was drawn from journals, newspapers, internet, periodicals and text books.

\section{Theoretical Framework \\ Resource Based Theory}

The resource based theory perspective argues that sustained competitive advantage is generated by the unique bundle of resources at the core of the firm (Corner and Prahalad, 2007; Barney2010). This implies that the resource based approach explains how business owners build their business from the resources and capabilities that they possessed or can acquire (Dollinger, 2008). The term "resources" was conceived broadly as"anything that can be thought of a strength or a weakness" of the firm (Wernerfelt, 2007). This theory addresses the central issue of how procurement process can 
INTERNATIONAL JOURNAL OF ACADEMIC RESEARCH IN BUSINESS AND SOCIAL SCIENCES Vol. 10, No. 4, April, 2020, E-ISSN: 2222-6990 @ 2020 HRMARS

be endowed with requisite inputs that can yield better performance by government corporations through service deliver and provision of tangible products. The theory further demystifies various inputs in the procurement process can be converted into valuable outcomes for economic transformation.

\section{Systems Theory}

Systems theory deals with cross-functional study of systems. A system a cohesive conglomeration of interrelated and interdependent parts that is either natural or manmade. Every system is defined by its longitudinal and sequential frontiers, surrounded and predisposed by its environment, described by its configuration and purpose or nature and expressed in its functioning. In terms of its outcome, a system can be more than the totality of its parts if it articulates interaction or evolving behavior. Changing one part of the system usually affects other parts and the whole system, with predictable patterns of behavior.

In most cases systems function mainly to compliment other systems by facilitating the maintenance of the other systems to avoid non-performance. The goal of systems theory is systematically discovering a systems dynamics, constraints, conditions and elucidating principles that can be discerned and applied to systems at every level of nesting and in every field for achieving optimized equifinality.

The systems theory highlights on the importance of procurement as the main link between the procurement service delivery team and the stakeholders who are the citizens. Procurement process is an interconnected system that creates a linkage for all the stakeholders right from the producer down to the consumer of goods or services.

\section{Expectancy Theory}

This has been an important theory in the history of the study of motivation. This theory highlights that motivation is partly a decision-making process that evaluates effort for outcomes. It highlights the involvement of the active cognitive processes and user choice in the process. It also highlights the importance of the outcome representing a valued reward for the individual involved (Galbraith, 1973)

The actual evaluation process is broken down into a number of parts: If I put in effort, can I expect to perform at the required task?, Will performing this act or task achieve a desired outcome?, Can I expect the outcome will be available and forthcoming?

Expectancy theory does highlight the significance of matching rewards for effort on an individual/personal basis. It focuses on the relationship between anticipated future rewards and present behavior. This theory therefore clearly demonstrates the role of procurement process in driving the overall organization agenda (Davis, 1989). The confines of this theory provide a basis for interrogating the rationale behind loss of public funds in the procurement process. Can the challenge of poor or good procurement practices be linked to the existing levels of motivation?

\section{Institutional Theory}

Institutional theory can be used to explain the challenges facing procurement process which in turn hampers organizational performance. (Obanda, 2010) observes that, institutional theory is normally used to examine public procurement from varying perspective. Theoretically, institutions are social 
INTERNATIONAL JOURNAL OF ACADEMIC RESEARCH IN BUSINESS AND SOCIAL SCIENCES Vol. 10, No. 4, April, 2020, E-ISSN: 2222-6990 @ 2020 HRMARS

structures that have attained high degree of resiliency they are composed of cultural-cognitive and regulative elements that, together with associated activities and resources give meaning to life (Scott, 2004). Scott, (2004) further explains that the mainstays of any institutions are regulatory, normative and cultural- cognitive, where regulatory refers to rules and laws and the enforcing mechanism, the normative elements includes norms and values while cultural-cognitive are the shared beliefs and understanding. In the context of this study, procurement processes are recognized as drivers of procurement entities as governed by the Public Procurement Disposal Act (PPADA, 2015). The process flow from need recognition to disposal should be viewed as an institutional framework for achieving the intended objectives of any government entity. This in turn will contribute to the achievement of key government agenda whose pillars are anchored on public entity's performance.

\section{Conceptual Framework}

The aim of this study is based on the fact that user departments play a critical role in driving the procurement process in the public sector. A responsive procurement process must be supported by the procurement plan, definition of specifications, evaluation and selection of the best suppliers and receiving of goods from vendors against the predetermined specifications (Lysons \& Farrington, 2012.

Fig 2.1 Conceptual Framework

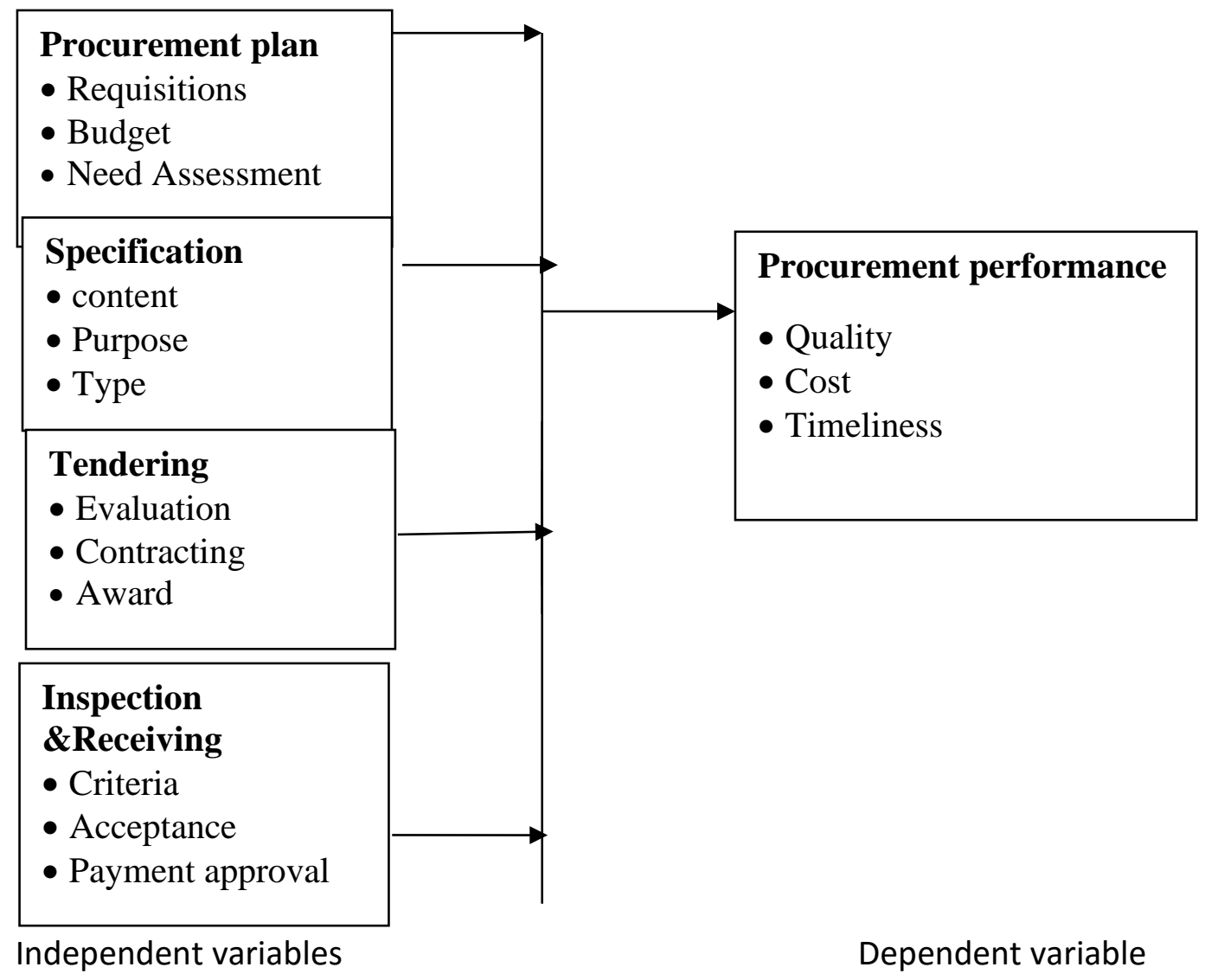

Source (Author, 2019) 
INTERNATIONAL JOURNAL OF ACADEMIC RESEARCH IN BUSINESS AND SOCIAL SCIENCES Vol. 10, No. 4, April, 2020, E-ISSN: 2222-6990 @ 2020 HRMARS

\section{Empirical Review of the Variables \\ Procurement Plan}

PPADA, (2015) provides that an accounting officer of a public procuring entity shall prepare an annual procurement plan which is realistic in a format set out in the regulations within the approved budget prior to commencement of each financial year as part of the annual budget preparation process. In addition all assets disposals shall be planned by the accounting officer concerned through annual asset disposal plan.

According to Ting, (2013), procurement plan is a document with designated details to enable appropriate consideration and approval for proposed procurement activities. Procurement planning involves preparing a detailed schedule of deciding what to buy, when and from what source and the cost implication. During the procurement planning process the procurement method is assigned and the expectations for fulfillment of procurement requirements determined. Basically, procurement planning defines a process whereby procurement professionals establish what needs to be procured (goods, services or works), when they need to be procured (contract timeframes) and from what source (identifying suitable contractors and vendors).

According to Lysons and Farrington (2012) Procurement planning has numerous benefits, such as: It provides an opportunity for all stakeholders to meet and discuss procurement requirements and objectives. The stakeholders could include anyone from end users, technical experts, Finance and members of the procurement department. Ensuring all relevant parties are involved in the planning process aids the development of a robust plan and ensures that procurement activities are effectively executed.

The planning process enables an organization to establish procurement requirements, assign them individual time frames and award contracts. It also facilitates determination of time frames set by requesting parties whether they are realistic or not (Howardell, 2010).

\section{Specification Writing}

The paradigm shift in modern business models where firms are focusing on strategic procurement; the accuracy, clarity and timeliness of specifications are becoming increasingly important. Value for money cannot be achieved without verifiable specifications since they form the basis for the prices quoted by contractors. This is because accurate specifications enhances the procurement cycle; a poorly written or structured specification can be a major reason why organizations fail to receive goods and services that ultimately meets the customer requirements. Goods and services provided by external firms are complex and these are key areas that require technical attention. Suppliers and contractors often use specifications and the subsequent contract as an opportunity to make claims and variations (Davis, 2013).

Specifications are divided into functional and technical specifications. Functional specifications refer to the documentation that describes the requested behaviour of a product or services. The documentation typically describes what is needed by the user as well as requested properties of inputs and outputs. Technical specification describes the explicit characteristics of an item, product or service required by the user department. It is critical to note that Specifications must not conflict with national or international standards or health, safety or environmental laws and regulations. National and international specifications should be incorporated into individual specifications and identified by their numbers and titles (Naylor, 2012). 
INTERNATIONAL JOURNAL OF ACADEMIC RESEARCH IN BUSINESS AND SOCIAL SCIENCES Vol. 10, No. 4, April, 2020, E-ISSN: 2222-6990 @ 2020 HRMARS

\section{Tendering}

According to Samuel (2012) Evaluation refers to the process of reviewing all the relevant information regarding a bid and developing weight on reviewing the criteria that establishes the standards by which to measure how well the supplier's approach meets the needs of the requesting department or the performance requirements.

The establishment of this criterion is critical, since only those standards listed in the requisition and subsequent bid documents can be considered in the evaluation of competing bidders. It also involves the evaluation committee reviewing the bids and awarding scores against a pre-determined criterion as outlined in the bid document. Once a scoring system has been devised, it must be impartially applied to each bidder (Lysons \& Farrington, 2012).

The Procurement Act, further provides that the evaluation committee shall prepare an evaluation report containing a summary of the evaluation and comparison of tenders which shall then be submitted to the person responsible for procurement to review and make recommendations to the Accounting officers. An evaluation committee may after tender evaluation, but prior to the award of the tender, conducts due diligence and present the report in writing to confirm and verify the qualifications of the tenderer who submitted the lowest evaluated responsive bid to be awarded the contract in accordance with the procurement law (PPDA, 2015).

Tender evaluation exercise should be carried within the stipulated period usually thirty days from the date of tender opening, failure to which may lead to termination of the tender. It is therefore important to adhere to evaluation timelines to ensure tenders are evaluated within the specified time to enhance award of tenders and mitigate against unnecessary termination. Prolonged tender evaluation may be costly to the organization because evaluation committee members require resource facilitation. To fast rack this exercise, the user department and procurement need to work in harmony to address issues that delay the evaluation process (Lewis \& Roehrich, 2009)

\section{Inspection and Receiving}

Receiving refers to the inbound process of getting consignments of materials and related consumables from the external suppliers. In involves checking and inspecting goods, works and services against the specifications provided in the contract document (Day, 2012).

Delivery of requested products or services marks a transition in the procurement process from purchasing activity to an account payable and user needs fulfillment activity. For this transition to be successful the vendor must properly execute delivery of the order and the user must inspect and ascertain that the goods meet the required specifications. When the supplier delivers the products or services, the Inspection and Acceptance Committee in liaison with the user must compare what has been delivered against the specifications in the contract document. The concerned user department has the responsibility of verifying and signing for satisfactory delivery of goods and services (Cooper, 2012)

Inspection and acceptance should be done based on the user specification to ensure an organization get value for money spent, at the same time reduce chances of receiving inferior products which may not meet the user requirements. Receiving of substandard goods may expose an organization to loss of funds as this may call for repeat purchase to ensure user satisfaction. Procurement and user departments need to carefully coordinate the receipt function to ensure value for money paid for goods and services, (Pennella, 2009) . 
INTERNATIONAL JOURNAL OF ACADEMIC RESEARCH IN BUSINESS AND SOCIAL SCIENCES Vol. 10, No. 4, April, 2020, E-ISSN: 2222-6990 @ 2020 HRMARS

\section{Procurement Process}

According to PPDA (2015) subject to procurement planning the accounting officer shall commence the procurement process through an invitation to tender, receive and open bids, evaluate bids, award contract, preparation and signing of the contract, contract management, inspection and acceptance and finally storage and inventory management.

All steps of the procurement process must be documented with each step being approved by the designated authority. All procurement documentation shall be properly filled. The processing and management of the complete procurement cycle require close coordination with the budget process, commitment control, finance and expenditure management, and audit. The Accounting officers must therefore ensure close coordination between the procurement function and the other budget functions (PPDGM, 2012).

Procurement process is a set of stages that takes place from when a need is identified until the final satisfactory delivery is made and the supplier paid. The main link in the procurement process is information and the main challenge lies with managing information at all phases of the process to ensure the requirements of the final customer are met or exceeded. The first step in procurement process begins with a request from the user department which can either be done electronically or written. However, in the public sector the first step in the process is the preparation of a procurement plan (Lysons \& Farrington, 2012).

The backbone of the procurement process is the preparation and signing of the contract with the winning bidder. The contract specifies the obligations of the procuring entity and the contractor giving timelines on the contract execution. The inspection and acceptance committee that is appointed by the Accounting officer does the inspection and receiving of goods and services by ensuring conformity with the specifications. The procurement process ends when the supplier is paid and subsequent records maintained ( PPDA, 2015).

\section{Methodology}

Introduction

This chapter discussed the methodology and approaches that were used in the study and highlighted aspects such as the research designs, target population, sampling technique, sampling frame, sample size, data collection procedures as well as data analysis and presentation.

\section{Research Design}

This study adopted both descriptive research design and quantitative research design. A research design is a plan for collecting and utilizing data so that desired information can be obtained (Orodha, 2009).The research design constitutes the blue print for data collection, measurement and analysis. It serves as the conceptual structure for conducting research. (Kothari, 2004). This study will employ descriptive research design as well as quantitative research design in order to gather adequate data from the respondents.. This will enable the researcher to have an in-depth account of all the variables of the study .Cooper and Schindler (2003) asserts that case studies place more emphasis on a full contextual analysis of fewer events or conditions. Descriptive research design enable the researcher to clearly define what he want to measure and provides adequate methods for measuring with a clear definition of the population of study. It aims at obtaining complete and accurate information from the respondents (Mugenda and Mugenda, 2003). The selected units in a case study are studied 
INTERNATIONAL JOURNAL OF ACADEMIC RESEARCH IN BUSINESS AND SOCIAL SCIENCES Vol. 10, No. 4, April, 2020, E-ISSN: 2222-6990 C 2020 HRMARS

extensively where the study extends over a period of time to ascertain substantive history of the units so as to obtain enough information for drawing correct inferences (Bryman\& Bell, 2003).

\section{Population}

According to Kothari (2006), target population is the total collection of elements about which one wishes to make some inferences. It is divided into two; target population and study population. Target population describes the large population where the small population is coming from while study population is the smaller population to be used in the research (Mugenda \& Mugenda, 2003). The population for this study was drawn from the employees of Nairobi county government. The target population will comprise of 1,000 employees in Nairobi county government.

Nairobi County was of interest to this study because the research is based on public entities in Kenya and Nairobi County having the majority of public entities and consequently contributing $40 \%$ of our GDP, the researcher purposively selected it (KNBS, 2018).

\section{Sampling Frame}

Sampling frame refers to the list of items or respondents which sample has to be drawn, it constitutes all the components of the study population (Dempsey, 2006).

In this study, the sampling frame was drawn from staff in the Procurement, Finance, ICT, Transport, Human Resource, Estate, Security, and administration. The total number of targeted employees working in these departments at Nairobi County government was 1,000 according to county public service board. For this study the sampling frame was 1000 employees who were directly and indirectly involved in the procurement process.

\section{Sample and Sampling Technique}

Due to homogeneity of the population the study will apply simple random sampling to select the sample size. This is because simple random sampling gives an equal chance to every respondent in the target population thus minimizing on biasness as well as making it easy to generalize and gather the findings (David, 2011). The number of employees directly and indirectly involved in the management of procurement process at Nairobi county government was 1000. A sample size of 100 from a target population of 1000 employees was selected. This fulfills the minimum threshold sample size suggested by Patton (2012) who recommended $10 \%$ of the target population as an adequate sample in a descriptive case study. Sampling was done as indicated in the table below. 
INTERNATIONAL JOURNAL OF ACADEMIC RESEARCH IN BUSINESS AND SOCIAL SCIENCES Vol. 10, No. 4, April, 2020, E-ISSN: 2222-6990 @ 2020 HRMARS

Distribution of Sampled Population of Nairobi county User Departments

\begin{tabular}{|l|l|l|}
\hline Department & Number & Percentage \\
\hline Procurement & 18 & 18 \\
\hline Finance & 16 & 16 \\
\hline ICT & 12 & 12 \\
\hline Transport & 10 & 10 \\
\hline Human Resource & 11 & 11 \\
& & \\
\hline Estate & 10 & 10 \\
\hline Security & 10 & 10 \\
\hline Administration & 13 & 13 \\
\hline Total & 100 & $100 \%$ \\
\hline
\end{tabular}

\section{Instruments}

According to Orodho (2009), data collection method is a tool that is used for data collection in a manner that is both objective and systematic. The study employed questionnaire as the primary data collection method. The questionnaires contained both open ended and closed ended questions. Questionnaires are effective instruments since they allow the respondents to give much of their opinion as far as the research problem is concerned (Dempsey, 2008).According to Kothari (2006), Information obtained from questionnaires is free from any bias and influence from the researchers. Owing to these reasons, questionnaires will be viable method for this study.

\section{Data Collection Procedures}

The study will involve collection of both primary and secondary data. Data collection procedure is the process of gathering pieces of information that are necessary for research process (Morris,2007). The primary data provides a presentation of the actual information that will be obtained to achieve the aim of the study. Primary data was collected using both open ended and closed ended questionnaires. The instruments were self-administered to the 100 respondents who will be selected for the purposes of analysis. Empirical and theoretical literature from journals, books and publications were reviewed to provide secondary data.

\section{Pilot Study}

A pilot study was used to reveal the weaknesses, if any, in the research design and instrumentation in order to provide proxy large scale studies for selection of probability sample (Cooper \& Scindler, 2006).A pilot or a feasibility study is a small experiment designed to test logistics and gather information prior to a large study in order to improve the latter's quality and efficiency.

It can reveal deficiencies in the design of a proposed experiment or procedures and these can then be addressed before time and resources are expended on the study (Cooper \& Schindler, 2006).

In order to ensure the validity of the study instrument, the study undertook a pre-test study by administering a questionnaire to 10 individuals from the target sample. According to Mugenda and Mugenda (1999) a successful pilot study uses $1 \%$ to $10 \%$ of the actual sample size. 
INTERNATIONAL JOURNAL OF ACADEMIC RESEARCH IN BUSINESS AND SOCIAL SCIENCES Vol. 10, No. 4, April, 2020, E-ISSN: 2222-6990 @ 2020 HRMARS

\section{Data Analysis and Presentation}

According to Mugenda and Mugenda (1999), data analysis seeks to make general statement on how categories or themes of data are related. The generated both qualitative and quantitative data owing to the nature of the instrument adopted which included both open and closed ended questions. Qualitative analysis involved coding and organizing collected data into themes and concepts that address the research questions. Descriptive statistics in the form of frequencies, pie charts and percentages were used for analysis in this study. Further data analysis was done using statistical package for social sciences.

\section{Research Findings and Discussions}

Introduction

This chapter presents the key findings of the study and the results of data analysis. The data was collected between October 2019 and February 2020. The general objective of the study was to determine the influence of procurement process on the performance of public procuring entities in Kenya. The specific objectives of the study were to examine the role of specification writing on the performance of public entities in Kenya; To investigate the influence of procurement plan on the performance of public entities in Kenya; To assess the effect of tender evaluation on the performance of public entities in Kenya; To determine the influence of receiving procedure on the performance the public entities in Kenya..

The primary data was collected from 92 individuals out of the 100 respondents who were targeted as some respondents declined to respond to the questionnaires. The respondents were categorized based on their respective departments which included: Procurement, Finance, ICT, Transport, Human Resource, Estate, Security, and administration. The reviewed literature was linked with the findings of the study to enable data interpretation, drawing of implications and the recommendations for the study. Descriptive statistics, correlations and regression analysis were used to analyze the empirical findings. This chapter is outlined as follows: response rate, sample characteristics, data management, descriptive, correlation and regression analysis under each of the study objectives.

Objective 1 To investigate the influence of procurement plan on the performance of public entities in Kenya

\section{Descriptive Analysis of Procurement Planning}

The study sought to determine the influence of procurement plan on performance of public entities in Kenya. The following indicators were used to measure this objective: Requisitioning, budget and Need assessment. The respondents were asked to indicate the extent to which they agreed with the procurement planning influence on performance of public entities. This was on a likert scale strongly agree, agree, neutral, disagree or strongly disagree.

Majority of the respondents (58.9\%) strongly agreed that requisitioning affects firms performance, $5.2 \%$ of the respondents disagreed, $10.2 \%$ were neutral while $2.3 \%$ strongly dagreed that requisitioning affects firm's performance (Mean $=3.72$, SD $=0.784)$. Majority $(57.8 \%)$ also strongly agreed timeliness is a critical ingredient for the performance of public entities, $31.8 \%$ agreed, $6.1 \%$ were neutral while the minority $4.3 \%$ strongly disagreed that timeliness was critical for the performance of public entity. (Mean $=3.91, \mathrm{SD}=0.903$ ). On the other hand, majority of the 
INTERNATIONAL JOURNAL OF ACADEMIC RESEARCH IN BUSINESS AND SOCIAL SCIENCES Vol. 10, No. 4, April, 2020, E-ISSN: 2222-6990 @ 2020 HRMARS

respondents (56.9\%) strongly agreed that budgeting influences performance, $24.6 \%$ of the respondents were neutral, $12.5 \%$ of the respondents , $(4.3 \%)$ strongly disagreed and also (1.7\%) strongly agreed (Mean $=3.83, \mathrm{SD}=1.140)$. In addition, a large number of the respondents $(59.7 \%)$ agreed that need assessment affects public entity performance. $20.9 \%$ also strongly disagreed, $11.4 \%$ were neutral, $5.2 \%$ agreed while a small number $4.8 \%$ strongly agreed (Mean $=3.29, \mathrm{SD}=1.185$ ).

The highest mean was 4.29 with the lowest being 3.72. This showed that the respondents took a positive position about the procurement planning (above 3.0). All the items had a mean abov3 3.0. This showed that the general position was that procurement process was present among the public entities in Kenya as shown in table 4.12.

Table 4. 1: Procurement plan

\begin{tabular}{lllllll}
$\mathrm{SD} \%$ & $\mathrm{D} \%$ & $\mathrm{~N} \%$ & $\mathrm{~A} \%$ & $\mathrm{SA} \%$ & $\mathrm{M}$ & $\mathrm{SD}$ \\
\hline
\end{tabular}
a) Requisitioning
44.9
40.6
11.6
2.9
3.72 .784

b) Timeliness

34.8

$47.8 \quad 10.1$

$5.8 \quad 1.4$

3.91 .903

c) Budgeting

9.2

36.9

24.6

$20.0 \quad 9.2$

3.831 .140

d) Need assessment

27.9

$39.7 \quad 13.2$

$13.2 \quad 5.9$

4.291 .185

Key: SD (Strongly Disagree), D (Disagree), N (Neutral), A (Agree), SA (Strongly Agree), SD (Strongly Disagree)

In general, the study found out that public entities in Kenya are guided by the procurement plan as the first step in procurement process. This is in tandem with PPADA (2015) which stipulate that all public procuring entities must have a procurement plan in place before they embark on procurement process.

However, the study found out that public entities in Kenya do put much emphasis on need assessment while preparing the procurement plan in addition, public entities in Kenya lack appropriate mechanism for implementing budget to the letter. A study by Lewis (2009) suggests budget ensures the procurement plan is implemented to the letter and the public achieves value for money.

Objective 2: To examine the role of specification writing on the performance of public entities in Kenya

\section{Descriptive Analysis of Specification Writing}

The study sought to determine the specifications on the performance of public entities in Kenya. Specification content, purpose of specifications and type of specifications were the parameters that were used to measure this objective in the opinion statements that were given by the respondents. 
INTERNATIONAL JOURNAL OF ACADEMIC RESEARCH IN BUSINESS AND SOCIAL SCIENCES Vol. 10, No. 4, April, 2020, E-ISSN: 2222-6990 @ 2020 HRMARS

The respondents were asked to indicate the extent to which they agreed with reduced performance as a result of better financial flow risk in their manufacturing firms. This was based on a likert scale of strongly disagree, disagree, neutral, agree and strongly agree as

The research observed that majority of the respondents (57.1\%) strongly agreed that their firms considers the content of specification, $34.3 \%$ agreed, $5.7 \%$ disagreed while the minority $1.4 \%$ strongly disagreed and also neutral. (Mean $=4.40, \mathrm{SD}=0.891$ ). A large number of the firms $(33.3 \%)$ strongly disagreed that they were not able to pay their suppliers on time, $27.5 \%$ disagreed, $17.4 \%$ agreed, $13.0 \%$ were neutral while a small number $8.7 \%$ strongly agreed (Mean $=2.41, \mathrm{SD}=1.343$ ).

This means that manufacturing firms in Kenya are able to pay their suppliers on time. These research findings are in agreement with the findings of a research carried out by Musa (2012) that the financial position of a firm is disrupted when a firm is unable to settle its debts. The findings also add that buying goods and services that are not required by the firm also affects the firm performance.

Table 4. 13: Specification

\begin{tabular}{lllllll}
$\mathrm{SD} \%$ & $\mathrm{D} \%$ & $\mathrm{~N} \%$ & $\mathrm{~A} \%$ & $\mathrm{SA} \%$ & $\mathrm{M}$ & $\mathrm{SD}$ \\
\hline
\end{tabular}
a) Content
44.9
40.6
11.6
2.9
$4.72 \quad .784$

b) Purpose

34.8

$47.8 \quad 10.1$

$5.8 \quad 1.4$

3.91 .903

c) Type

9.2

36.9

24.6

$20.0 \quad 9.2$

4.831 .140

d) Need assessment

27.9

$39.7 \quad 13.2$

$13.2 \quad 5.9$

4.291 .185

Key: SD (Strongly Disagree), D (Disagree), N (Neutral), A (Agree), SA (Strongly Agree), SD (Strongly Disagree)

Objective 3: To assess the effect of tendering process on the performance of public entities in Kenya The study sought to determine the specifications on on the performance of public entities in Kenya. Specification content, purpose of specifications and type of specifications were the parameters that were used to measure this objective in the opinion statements that were given by the respondents. The respondents were asked to indicate the extent to which they agreed with reduced performance as a result of better financial flow risk in their manufacturing firms. This was based on a likert scale of strongly disagree, disagree, neutral, agree and strongly agree as

The research observed that majority of the respondents $(57.1 \%)$ strongly agreed that their firms considers the content of specification, $34.3 \%$ agreed, $5.7 \%$ disagreed while the minority $1.4 \%$ strongly disagreed and also neutral. (Mean $=4.40, S D=0.891)$. A large number of the firms $(33.3 \%)$ strongly disagreed that they were not able to pay their suppliers on time, $27.5 \%$ disagreed, $17.4 \%$ agreed, $13.0 \%$ were neutral while a small number $8.7 \%$ strongly agreed ( $M e a n=2.41, S D=1.343$ ). 
INTERNATIONAL JOURNAL OF ACADEMIC RESEARCH IN BUSINESS AND SOCIAL SCIENCES Vol. 10, No. 4, April, 2020, E-ISSN: 2222-6990 @ 2020 HRMARS

This means that manufacturing firms in Kenya are able to pay their suppliers on time. These research findings are in agreement with the findings of a research carried out by Musa (2012) that the financial position of a firm is disrupted when a firm is unable to settle its debts. The findings also add that buying goods and services that are not required by the firm also affects the firm performance.

Table 4. 14: Tendering

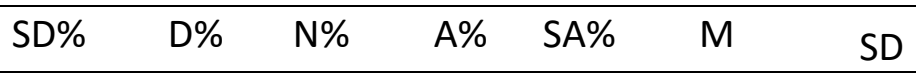

$\begin{array}{llllll}\text { a) Evaluation } & 44.9 & 40.6 & 11.6 & 2.9 & 4.72\end{array}$

$\begin{array}{llllllll}\text { b) Contract management } & 34.8 & 47.8 & 10.1 & 5.8 & 1.4 & 3.91 .903\end{array}$

$\begin{array}{llllllll}\text { c) Contract Award } & 9.2 & 36.9 & 24.6 & 20.0 & 9.2 & 4.83 & 1.140\end{array}$

Key: SD (Strongly Disagree), D (Disagree), N (Neutral), A (Agree), SA (Strongly Agree), SD (Strongly Disagree)

Objective 4: To determine the influence of Inspection and receiving procedure on the performance the public entities in Kenya

Objective 3: To assess the effect of tendering process on the performance of public entities in Kenya The study sought to determine the specifications on on the performance of public entities in Kenya. Specification content, purpose of specifications and type of specifications were the parameters that were used to measure this objective in the opinion statements that were given by the respondents. The respondents were asked to indicate the extent to which they agreed with reduced performance as a result of better financial flow risk in their manufacturing firms. This was based on a likert scale of strongly disagree, disagree, neutral, agree and strongly agree as

The research observed that majority of the respondents $(57.1 \%)$ strongly agreed that their firms considers the content of specification, $34.3 \%$ agreed, $5.7 \%$ disagreed while the minority $1.4 \%$ strongly disagreed and also neutral. (Mean $=4.80, \mathrm{SD}=0.891)$. A large number of the firms $(33.3 \%)$ strongly disagreed that they were not able to pay their suppliers on time, $27.5 \%$ disagreed, $17.4 \%$ agreed, $13.0 \%$ were neutral while a small number $8.7 \%$ strongly agreed (Mean $=4.41, \mathrm{SD}=1.343$ ).

This means that manufacturing firms in Kenya are able to pay their suppliers on time. These research findings are in agreement with the findings of a research carried out by Musa (2012) that the financial position of a firm is disrupted when a firm is unable to settle its debts. The findings also add that buying goods and services that are not required by the firm also affects the firm performance. 
INTERNATIONAL JOURNAL OF ACADEMIC RESEARCH IN BUSINESS AND SOCIAL SCIENCES Vol. 10, No. 4, April, 2020, E-ISSN: 2222-6990 C 2020 HRMARS

Table 4. 15: Inspection and Receiving

$\begin{array}{lllllll}\mathrm{SD} \% & \mathrm{D} \% & \mathrm{~N} \% & \mathrm{~A} \% & \mathrm{SA} \% & \mathrm{M} & \mathrm{SD}\end{array}$

$\begin{array}{llllll}\text { a) Evaluation } & 44.9 & 40.6 & 11.6 & 2.9 & 4.72\end{array}$

b) Contract management

34.8

$\begin{array}{llll}47.8 & 10.1 & 5.8 & 1.4\end{array}$

3.91 .903

c) Contract Award

9.2

$36.9 \quad 24.6$

20.09 .2

3.831 .140

Key: SD (Strongly Disagree), D (Disagree), N (Neutral), A (Agree), SA (Strongly Agree), SD (Strongly Disagree)

\section{Summary Conclusions and Recommendation}

Introduction

This chapter provides a summary of the study major findings and also draws the conclusions, makes recommendations for practice and provides suggestion for further research based on the study findings.

\section{Summary}

The overall objective of this study was to determine the influence of procurement process on the performance of public procuring entities in Kenya. The study particularly sought to investigate the influence of procurement plan on the performance of public entities in Kenya; to examine the role of specification writing on the performance of public entities in Kenya; to assess the effect of tendering process on the performance of public entities in Kenya; to determine the influence of Inspection and receiving procedure on the performance the public entities in Kenya.

\section{Influence of procurement plan on the performance of public entities in Kenya}

Procurement Plan is an annual document which defines the products and services that a Public Body will obtain from external suppliers. A sound procurement plan helps a Procuring Entity to define their procurement requirements and to decide where and when to procure. Information flow risk in this study was measured using information accuracy, information types and information connectivity. The study established that that public entities relies on the procurement plan to manage procurement activities through strict adherence to budgetary provisions. However, the study found out that public entities in Kenya do not frequently conduct need assessment before embarking on a major purchase which may lead to loss of funds or failure to achieve optimal value for money.

Public entities in Kenya often leverage on purchase requisition vouchers, annual budgeting and user requirements to achieve responsiveness in the procurement function and in the organization as a whole. 
INTERNATIONAL JOURNAL OF ACADEMIC RESEARCH IN BUSINESS AND SOCIAL SCIENCES Vol. 10, No. 4, April, 2020, E-ISSN: 2222-6990 @ 2020 HRMARS

Moreover, there was no significant relationship between need assessment and performance. This means that need assessment does not influence the performance of public entities in Kenya.

\section{Role of specification writing on the performance of public entities in Kenya}

Specification refers precise description of the physical characteristics, quality, or desired outcomes of a commodity to be procured, which a supplier must be able to produce or deliver to be considered for award of a contract. The study found out that public entities in liaises with the user as well as the supplier when determining the content of the specification is also highly considered specification. The purpose of specification is also included in the overall specification set to justify particularly when detailed specifications have a relatively huge cost implication on the cost of a service or commodity . Also, most of the materials purchased by the public entities were done with strict adherence to detailed specification.

In addition, public procurement entities in Kenya adopt various types of specifications among them design specifications, material specifications, standard specifications, interface specifications, test specifications, performance speculations and quality specifications. Application of these types of specifications depended on nature of items or service being procured.

\section{Effect of tendering process on the performance of public entities in Kenya.}

Tendering is the process of identifying potential suppliers, selecting the most responsive supplier based on pre-determined criteria such as financial and technical aspects and then forming a legally binding contract with the most appropriate supplier. The study found out that public entity in Kenya follows a laid down procedure through physical examination of tender documents in conducting tender evaluation. It further emerged that tender evaluation is divided into two parts; technical and financial evaluation with preliminary evaluation checking on mandatory requirements. The study also found maximum period for evaluation as prescribed by the law was observed.

The study further found that notification of the successful bidders was done within 24 years after the completion and the cases of contract breach by any of the parties were minimal. In addition the contract further found that contract award was based on the most responsive evaluated bid on both technical and financial perspectives. In some instances contract award notification was done electronically.

To determine the influence of Inspection and receiving procedure on the performance the public entities in Kenya.

Inspection and receiving refers to the validation of purchased goods thorough pre-determined criteria in order to establish whether the said goods meet a given set of specifications as outlined by the user. The study found out that the public entity had designated bays for inspection and receiving of goods where the delivery date is normally pre-determined.

In addition, acceptance of goods is based on comprehensive inspection where adherence to specifications is determined before goods are officially received. Receiving of goods is executed through signing of official documents such as delivery notes and inspection report. The study further found that after the receipt of the goods payment is done to the suppliers within a prescribed period of time although there are often cases of delays in payment. Approval for payment is done by a designated official with powers to authorize up to a given limit. 
INTERNATIONAL JOURNAL OF ACADEMIC RESEARCH IN BUSINESS AND SOCIAL SCIENCES Vol. 10, No. 4, April, 2020, E-ISSN: 2222-6990 @ 2020 HRMARS

\section{Influence of procurement process on the performance of public procuring entities in Kenya}

On the combined relationship between procurement process (procurement plan, specifications, tendering, inspection and receiving) and firm performance of public entities the descriptive statistics revealed the relationship was high. This is because the combine mean was high (above, 2.5). All the variables (procurement plan, specifications, tendering. This is in agreement Kiage (2013) on factors affecting procurement performance which includes: tendering process, specifications and procurement plan.

\section{Conclusions}

Influence of procurement plan on the performance of public entities in Kenya

The findings confirm that there is strong statistically significant relationship between procurement plan and performance performance of public entities in Kenya. This can be explained by the fact that, procurement plan is a mandatory requirement. These results are in line with Kiage (2013) who explained that elements of procurement process are key drivers of achieving responsiveness in procurement

Procurement process is a critical pillar for driving performance of public procuring entities since it creates a pro-active mechanism for identifying organization needs based on the pre-existing budgetary provisions and thus making it possible to achieve value for money through adoption of financial and procurement control mechanisms.

\section{Role of specification writing on the performance of public entities in Kenya}

The study concluded that there was a strong significant relationship between specifications and performance of public entities in Kenya. Therefore, specifications significantly predict the performance of public entities in Kenya (product or service specification affects performance). This is explained by the descriptive results which revealed that public entities in Kenya are concerned about detailed description of goods and adherence to specifications for both products and services. PPADA (2015) outlines that before purchase is effected the user should provide detailed specifications of the purchase in question.

\section{Effect of tendering process on the performance of public entities in Kenya}

The study concluded that tendering significantly affect the performance of public entities in Kenya. This is demystified by the fact that public entities in Kenya are cognizant of the fact that tendering is the key driver of procurement process and the laid down procedure by the law should be followed to the letter. All the key stages right from advertisement for the process to the receiving of the bids, bid opening, preliminary evaluation and contract management are all critical stages that guides tendering process. The chronology of events leading to successful award of the bid is a key driver of transparency, competition and achievement of value for money by the public procuring entities.

Influence of Inspection and receiving procedure on the performance the public entities in Kenya The findings of this study confirm that inspection and receiving is significantly influences the performance of public entities in Kenya. It was possible to infer form the study that the relationship between inspection and receiving and the performance of public entities in Kenya was positive and significant. We can therefore conclude that as the prominence role of receiving and inspection 
INTERNATIONAL JOURNAL OF ACADEMIC RESEARCH IN BUSINESS AND SOCIAL SCIENCES Vol. 10, No. 4, April, 2020, E-ISSN: 2222-6990 @ 2020 HRMARS

increases, the performance of public entities in Kenya increases. Considering all public entities in Kenya are bound by the provisions of public procurement and asset disposal Act of 2015 which provides guidelines on inspection and receiving procedure.

\section{Influence of procurement process on the performance of public procuring entities in Kenya}

All the independent variables (procurement plan, specification, tendering and receiving and inspection) were determined to be significant predictors of the performance of public entities in Kenya particularly Nairobi county government. This can be explained by the results from various public entities that have adopted the above aspects and have successfully managed to achieve value for money and competitiveness of procurement processes. This can result in in overall process responsiveness which significantly improve the performance of a firm.

\section{Recommendations}

\section{Influence of procurement process on the performance of public entities}

Public entities should have a clearly outlined procurement plan indicating the specific quantities of items to be bought and their respective budget. This would serve to ensure no purchases are done outside the contractual arrangements as stipulated in the procurement budget. Procurement process allows public entities to determine if expectations are realistic; particularly the expectations of the requesting entities, which usually expect their requirements met on short notice and over a shorter period than the application of the corresponding procurement method allows. In Addition it permits the creation of a procurement strategy for procuring each requirement that will be included in the procurement plan. Such strategy includes a market survey and determining the applicable procurement method given the requirement and the circumstances.

\section{Influence of procurement plan on the performance of public entities in Kenya}

Procurement plan lays down the key the key fundamental preliquisites that guides the procurement process of a public entity within a given financial year. It factors in the entire requirement for goods and services and respective budget. However there are instances where there are changes in the quantity required or a new need is identified. This gap is bridged through preparation of a supplementary plan backed by a supplementary budget to cater for the variances between the actual requirements and the planned quantities.

\section{Role of specification writing on the performance of public entities in Kenya}

Specifications preparation is a key function that typically acts as an interface between the customer and suppliers by primarily taking a business requirements and exploding them into a detailed description of the specific requirements. Specifications can be attributed to two aspects- things which includes components and raw materials and actions which relates to functions, processes, procedures, services and performance. (Lysons, 2012).

\section{Effect of tendering process on the performance of public entities in Kenya}

This study recommends that public entities in Kenya should adhere to the provisions of tendering process as outlined in Public Procurement and Asset Disposal Act of 2015. This would ensure smooth flow of all activities right from tender advertisement, receiving and opening of the bids and the actual 
INTERNATIONAL JOURNAL OF ACADEMIC RESEARCH IN BUSINESS AND SOCIAL SCIENCES Vol. 10, No. 4, April, 2020, E-ISSN: 2222-6990 @ 2020 HRMARS

bid evaluation and award of the contract as a means of encouraging competition and transparency in the public procurement system. The study further recommends use of an hybrid of both manual and electronic means to ensure pertinent issues that cannot be tackled using one single approach are adequately addressed.

Influence of Inspection and receiving procedure on the performance the public entities in Kenya Considering the critical role played by inspection and receiving in the procurement process and consequently the performance of the manufacturing firms in Kenya, it is evident that public entities in Kenya should adhere to the guidelines on inspection and receiving since it is the end results that give a reflection of the entire procurement process. The study therefore recommends that public entities in Kenya should strictly adhere to the set criteria regarding the standards against which to inspect for compliance and then proceed to receive or reject goods from the supplier .

\section{Areas for Further Research}

The study limited itself to the four procurement process aspects, that is, procurement plan, specifications, tendering and inspection and receiving, from the literature that affect the performance of manufacturing firms in Kenya. This therefore meant that the empirical review that supports the above variables among public entities in Kenya was only limited to these four variables identified in the study. Therefore, similar study should be conducted with other variables that affect the procurement process and the performance of other firms. This study was also conducted in NairobiCounty in Kenya and data was collected in that County only. This study recommends that a similar study should be conducted in other counties in Kenya I order to come up with a variety of outcomes.

\section{References}

Atken. (2009). Logistics and supply chain management, ( $2^{\text {nd }}$ ed). Pearson

Day, M. (2012). Hand book of Purchasing and supplies management, ( $\left.3^{\text {rd }} \mathrm{ed}\right)$. Grower. London

David, P. (2011). Using mixed methods: frameworks for an integrated methodology. ( $1^{\text {st }}$ ed).Sage. New Delhi

G. O. K. (2009).The Republic of Kenya Procurement Manual for Works.First Edition.

Cartlidge, D. (2002). New aspects of quantity surveying practice, UK: Butterworth-Heinemann

Davis, T. (2013). Effective supply chain management, ( $3^{\text {rd }}$ ed). Prentice Hall

Donald, K. K., Delno, L., \& Tromp, A. (2006).Proposal Writting: An Introduction. Don Bosco Press.

GOK, Public procurement and Asset Disposal Act, (2015). Government press

International Organization for Standardization (ISO).2008. Draft International Standard - ISO/DIS 10845-1: Construction procurement.

Kenya Gazette Supplement No. 207 (Acts No. 33). 2015. Special issue. Government printer, NairobiLove, P. E. D., Skitmore, M. R., and Earl, G. (1998) 'Selecting an appropriate procurement method for the construction process: an empirical study', Construction Management and Economics, vol. 16, no. 2, pp.221-223.

Kiage, O. K. (2013). Factors affecting procurement performance. A case of Ministry of Energy, International Journal of Business and Commerce, 3(1), 54-70. 
INTERNATIONAL JOURNAL OF ACADEMIC RESEARCH IN BUSINESS AND SOCIAL SCIENCES

Vol. 10, No. 4, April, 2020, E-ISSN: 2222-6990 @ 2020 HRMARS

Kothari, C. R. (2008). Research Methodology; Methods and Techniques (2nd ed.). New Delhi: New Age International Press Limited.

Leenders, M. R., Johnson, P. F., Flyn, A. E., \&Fearson, H. E. (2006).Purchasing and Supplies Management (13th ed.). McGraw- Hill.

Lewis, M.A. and Roehrich, J.K. (2009), Contracts, relationships and integration: Towards a model of the procurement of complex performance. International Journal of Procurement Management, 2(2):125-142.

Lysons, K., Farrington and Brian. (2000). Purchasing and supply chain management. 7th edition,Financial Times/Prentice Hall, 2005; London.

Masterman, J. W. E. (2002). An introduction to building procurement systems, 2nd edition, London: Spon Press PILCHER, R. (1992) Principles of construction management, 3rd edition, Maidenhead, UK: McGraw-Hill Book Company.

Mohamed S. (2011), Modern Logistics management. (6 ${ }^{\text {th }}$ ed). Prentice Hall New York

Mugenda, O. M., \&Mugenda , A. G. (2003). Research Methods.Nairobi: Acts Press Oxford Univ Press OECD 2001.Working Paper No.208. OECD Development Centre.

Pennella, C., Robert (2006). Managing Contract Quality Requirements. American Society for Quality. pp. 48-49. ISBN 978-0-87389-694-8

PPOA. (2007). Assessing Procurement Systems in Kenya Report. Nairobi: Public Oversight Authority. Public Procurement and Disposal General Manual (2012). Government Press

Naylor, J. (2012). Introduction to procurement management. ( $3^{\text {rd }}$ ed). Prentice Hall.

Rameezdeen, R., and Ratnasabapathy, S. (2006).'A multiple decisive factor model for construction procurement system selection', Conference Proceedings of the 6th Annual Research Conference, the Royal Institution of Chartered Surveyors, September, University College London, UK.

Samuel, A. (2012). "Design-Build Procurement Approaches". In Shorney-Darby, Holly. Design-build for Water and Wastewater Projects. American Water Works Association. p. 73. ISBN 9781583218181. Retrieved 2015-12-03. An Expression of Int 